\title{
Maintenance of human skin in organ culture: role for insulin-like growth factor-1 receptor and epidermal growth factor receptor
}

Received: 29 March 1999 / Received after revision: 16 August 1999 / Accepted: 25 August 1999

\begin{abstract}
Recent studies have shown that adult skin incubated in low-Ca ${ }^{2+}(0.15 \mathrm{~m} M)$ medium rapidly degenerates but that normal architecture is maintained when the tissue is incubated in high-Ca ${ }^{2+}$ medium $(1.4 \mathrm{mM}$ $\left.\mathrm{Ca}^{2+}\right)$. To investigate whether the skin cell-produced growth factors insulin-like growth factor-1 (IGF-1) and epidermal growth factor (EGF) play a role in these events, 2-mm skin punch biopsies were obtained and maintained for 8 to 10 days in a basal medium containing $0.15 \mathrm{mM} \mathrm{Ca}{ }^{2+}$ with and without growth factors, or containing $1.4 \mathrm{mM} \mathrm{Ca}{ }^{2+}$ with and without antibodies to the same growth factors. In parallel experiments, cultured human keratinocytes were incubated for 2 days in the same basal medium in the presence or absence of the same growth factors and antibodies. Consistent with previous reports, organ cultures incubated in the low-Ca ${ }^{2+}(0.15 \mathrm{~m} M)$ medium rapidly degenerated. Neither IGF-1 nor EGF prevented the complete degeneration of epidermis and dermis in these organ cultures. Interestingly, the addition of an anti-IGF-1 receptor (IGF$1 R)$ antibody to the organ cultures maintained in high$\mathrm{Ca}^{2+}$ medium induced changes reminiscent of those seen when the organ cultures were maintained in low-Ca ${ }^{2+}$
\end{abstract}

\footnotetext{
A. Tavakkol

Skin Clinical Investigations Group, Colgate-Palmolive Company, Piscataway, NJ, USA

J. Varani

Department of Pathology,

The University of Michigan Medical School, Ann Arbor, Michigan, USA

J. T. Elder

Department of Dermatology,

The University of Michigan Medical School, Ann Arbor, Michigan, USA

Ch. C. Zouboulis (更)

Department of Dermatology,

University Medical Center Benjamin Franklin,

The Free University of Berlin, Hindenburgdamm 30, 12200 Berlin, Germany

Tel: +49-30-84452769, Fax: 49-30-84454262
}

medium, i.e. tissue degeneration. In contrast, antibodies to EGF receptor, used for comparison, only produced focal areas of epidermal necrosis. In vitro, IGF-1 is a known mitogen for keratinocytes. In cultured human keratinocytes, anti-IGF-1R antibody partially inhibited the IGF-1-mediated stimulation of human keratinocyte proliferation without affecting normal spontaneous growth. Additionally, IGF-1R immunolocalized to basal keratinocytes in vivo, exhibited specific binding to IGF-1 in vitro. This indicated a critical role for IGF-1R in both organ cultures ex vivo and cultured cells in vitro. Messenger RNA encoding both IGF-1 and IGF$1 R$ were readily detected by $R T-P C R$ in organ cultures incubated in both low- and high- $\mathrm{Ca}^{2+}$ medium. There were no detectable differences in IGF-1 mRNA in organ cultures growing in the low- or high- $\mathrm{Ca}^{2+}$ medium, but lower levels of IGF-1R mRNA were observed in the organ cultures maintained in low- $\mathrm{Ca}^{2+}$ medium than in those in high $\mathrm{Ca}^{2+}$ medium. These findings are consistent with homeostatic changes in the tissue grown under different calcium concentrations. IGF-1 mRNA was detected in several skin cell populations in vitro, even though it was undetectable in cultured keratinocytes. Taken together these findings indicate that (1) the IGF-I/ IGF-1 $R$ loop is critically involved in maintenance of human skin organ cultures ex vivo, and (2) IGF-1, locally produced by skin cells other than keratinocytes, interacts with its receptor, predominantly expressed in basal keratinocytes, to maintain tissue homeostasis.

Key words Insulin-like growth factor-1 - Insulin-like growth factor-1 receptor - Epidermal growth factor . Epidermal growth factor receptor · Epidermis

\section{Introduction}

Autocrine and paracrine signaling networks and single factors are known to be morphogens or mitogens for epidermal keratinocytes [1-3]. Although several studies have indicated that a large number of diverse factors are capable 
of stimulating keratinocyte cell growth in monolayer culture, it is difficult to know what role, if any, each one may play in vivo.

In recent studies, certain conditions have been identified that allow the preservation of human skin in organ culture [4-8]. It has been shown $[4,5]$ that normal histological structure and biochemical function can be maintained for 12-20 days under serum-free, growth factor-free conditions as long as the extracellular $\mathrm{Ca}^{2+}$ concentration is kept at a level which would support dermal fibroblast viability (above $1 \mathrm{~m} M$ [9]). Since structure and function can be maintained in the absence of exogenous growth factors, we presumed that organ-cultured skin is capable of producing whatever growth factors are required which act as autocrine or paracrine regulators. This is true for insulin-like growth factor-1 (IGF-1), which is produced by keratinocytes of the stratum granulosum and by dermal fibroblasts and activates its receptor on keratinocytes [8], as well as for heparin-binding epidermal growth factor-like growth factor and amphiregulin, which are produced by epidermal keratinocytes and activate the epidermal growth factor (EGF) receptor (EGF-R) [10]. Therefore, antibodies to these growth factors or their receptors would be expected to cause alterations in tissue homeostasis, which may be mitigated by growth factor addition. The present study was carried out in an effort to identify the role of IGF-1 receptor (IGF-1R) and of EGF-R. Our findings suggest that factors which function through the IGF-1R are important for preservation of human skin in organ culture. A role for factors which act through the EGF-R is also suggested.

\section{Materials and methods}

IGF-1, EGF, anti-IGF-1R antibodies and anti-EGF-R antibodies

Human recombinant IGF-1 and human recombinant EGF were obtained from Genzyme (Cambridge, Mass.). A mouse monoclonal anti-IGF-1R IgG antibody (designated as $\alpha$ lR-3) was obtained from Oncogene Sciences (Cambridge, Mass.). A mouse monoclonal antibody to the EGF-R (mAb 225) was kindly provided by Dr. John Mendelsohn (Sloan-Kettering Memorial Cancer Center). Normal mouse IgG was used as a control.

\section{Organ culture protocol}

Full-thickness punch biopsies $(2 \times 2 \mathrm{~mm})$ were obtained from the hips of healthy adult volunteers (normally eight biopsies per volunteer) and were immediately placed into the wells of a 24-well dish containing $0.5 \mathrm{ml}$ of keratinocyte basal medium (KBM; Clonetics, San Diego, Calif.). The $\mathrm{Ca}^{2+}$ concentration of $\mathrm{KBM}$ is $0.15 \mathrm{mM}$. One well was left without further treatment while in the duplicate well, calcium chloride was added to bring the final $\mathrm{Ca}^{2+}$ concentration to $1.4 \mathrm{~m} M$. Growth factors and antibodies to growth factor receptors were included in the culture medium as indicated. The organ cultures were then incubated at $37^{\circ} \mathrm{C}$ in an atmosphere containing $5 \%$ $\mathrm{CO}_{2}$ for 8-10 days with fresh culture medium and treatments provided at 2-day intervals.

\section{Histological evaluation of organ-cultured skin}

At the end of the experiment, the organ cultures were fixed in $10 \%$ phosphate-buffered formalin and embedded in paraffin. Sections were then cut at a thickness of $5 \mu \mathrm{m}$ and were stained with hematoxylin/eosin. Representative sections of each biopsy were selected for histological evaluation by examining for epidermal integrity, viability and structural preservation. Specifically, we searched for the presence of healthy, polarized cells in the basal layer. Numbers of non-pyknotic basal epithelial cells per unit length of basement membrane were counted at $200 \times$ magnification using a microscope with a calibrated grid in the eyepiece. In addition, the epithelium was examined for the presence of pyknotic nuclei (i.e. dark-stained, shrunken nuclei without evidence of chromatin structure) and for separation of the basal cells from the underlying basement membrane as indicators of necrosis. Finally, the epidermis was examined for the presence of the various stages of epithelial differentiation.

Evaluation of the dermis consisted of examining for the presence of healthy non-pyknotic interstitial cell nuclei as indicators of viability and for evidence of connective tissue degeneration. Evidence of dermal necrosis included: (1) interstitial nuclear pyknosis, (2) a bundled or granular appearance of the connective tissue elements instead of the normal fibrillar pattern, (3) extensive dermal edema, and (4) denudation of the endothelial cells from the dermal capillaries.

\section{Preparation of cells from skin}

Human epidermal keratinocytes were obtained as described previously [11] and maintained in keratinocyte growth medium (KGM; Clonetics). KGM consists of KBM supplemented with $0.1 \mathrm{ng} / \mathrm{ml} \mathrm{hu-}$ man recombinant EGF, $5 \mu \mathrm{g} / \mathrm{ml}$ insulin, $0.5 \mu \mathrm{g} / \mathrm{ml}$ hydrocortisone and $0.4 \%(\mathrm{w} / \mathrm{v})$ pituitary extract. The $\mathrm{Ca}^{2+}$ concentration of KGM is $0.15 \mathrm{~m} M$. This culture medium has proven satisfactory for the long-term cultivation and maintenance of human keratinocytes in an undifferentiated state. Fibroblasts were isolated from human skin [12] and maintained in minimal essential Eagle's medium with Earle's salts supplemented with non-essential amino acids, $10 \%$ fetal bovine serum, $100 \mathrm{U} / \mathrm{ml}$ penicillin and $100 \mu \mathrm{g} / \mathrm{ml}$ streptomycin. Human foreskin melanocytes were also used in certain experiments. These were obtained from the same cultures used to start keratinocytes as described previously [13] and maintained in melanocyte growth medium supplemented with basic fibroblast growth factor and phorbol myristate acetate (Clonetics). Human umbilical vein endothelial cells were obtained from cords and cultured in M199 medium supplemented with $20 \%$ fetal bovine serum, $25 \mu \mathrm{g} / \mathrm{ml}$ endothelial cell growth supplement and $90 \mu \mathrm{g} / \mathrm{ml}$ heparin [14].

In addition to these cells which were routinely cultured in vitro, we also obtained small numbers of skin-infiltrating $\mathrm{T}$ cells and Langerhans cells. T cells were isolated from a small piece of keratomed, adult epidermis from an untreated psoriatic plaque as previously described [15]. Langerhans cells were affinity-purified from keratinocyte cultures by first coating cells with mouse anti-CDla antibody (OKT6, Ortho, Raritan, N.J.) followed by incubation with goat anti-mouse IgG-coated magnetic beads (Dynabeads, Dynal, Norway) as described previously [16]. Finally, fresh keratome biopsies of human skin and human liver from autopsy tissue were used.

Preparation of RNA and mRNA phenotyping by reverse transcription-polymerase chain reaction (RT-PCR)

Total RNA was prepared from skin and liver and from keratinocytes, fibroblasts, melanocytes and human umbilical vein endothelial cells as described previously [17]. Langerhans cells and skininfiltrating $\mathrm{T}$ cells were obtained from skin biopsies and total RNA was prepared using the RNAzol RNA extraction kit (Cinna/ Biotech, Houston, Tex.) following the manufacturer's instructions.

RT-PCR was carried out in a Perkin Elmer Thermocycler (Cetus, Emeryville, Calif.) using $2.5 \mu \mathrm{g}$ of total RNA from tissues or cells. Total RNA was reverse transcribed to cDNA using random hexamers $(2.5 \mu \mathrm{M})$ and M-MLV reverse transcriptase (200 U; GIBCOBRL, Gaithersburg, Md.) in a total volume of $30 \mu \mathrm{l}$ at $37^{\circ} \mathrm{C}$ for $1 \mathrm{~h}$ and $75^{\circ} \mathrm{C}$ for $10 \mathrm{~min}$. The cDNA $(1 \mu \mathrm{l})$ was then amplified for 
30 cycles with $0.4 \mu \mathrm{M}$ gene-specific PCR primers and $5 \mathrm{U}$ Taq DNA polymerase (GIBCO-BRL) [18]. The reaction was initiated at $94^{\circ} \mathrm{C}$ for $2 \mathrm{~min}$; each amplification cycle consisted of $60 \mathrm{~s}$ at $92^{\circ} \mathrm{C}, 90 \mathrm{~s}$ at $55^{\circ} \mathrm{C}$ and $90 \mathrm{~s}$ at $72^{\circ} \mathrm{C}$. The final extension was for $10 \mathrm{~min}$. The tubes were cooled rapidly to $4^{\circ} \mathrm{C}$ and $40-\mu l$ aliquots were analyzed on $1.2 \%$ agarose gels. Gels were stained with ethidium bromide to visualize DNA bands and photographed. The oligonucleotide primers were based on the published nucleotide sequence of the $\alpha$-chain of human IGF-1R nucleotides 1147-1167 and 20572077 [19], human IGF-1 nucleotides 150-170 and 419-439 [20] and human CDla nucleotides 1559-1579 and 1883-1903 [21]. The identity of the PCR products was confirmed by enzyme restriction mapping and DNA blot hybridization with ${ }^{32} \mathrm{P}$-labeled specific cDNA probes as described previously [22]. All oligonucleotides were synthesized to specification by the University of Michigan DNA and Protein Core Facility.

\section{Semiquantitative RT-PCR}

To quantify IGF-1R gene expression semiquantitative RT-PCR of small amounts of total RNA $(0.7 \mu \mathrm{g})$ from individual samples $(n=4)$ was performed as previously described [23]. A total of 35 PCR cycles with the IGF-1R-specific primers were carried out, followed by gel electrophoresis, Southern blotting and hybridization against a specific ${ }^{32} \mathrm{P}-\mathrm{cDNA}$ probe for IGF-1R DNA.

\section{Monolayer culture assays}

Growth assays were carried out with keratinocytes in monolayer culture as follows. Cells were seeded into 24 -well dishes at $4 \times 10^{4}$ cells per well in KGM and allowed to attach. The culture medium was then removed and the cells washed twice in KBM. Fresh KBM with or without growth factors and antibodies to growth factor receptors were added as indicated. The cells were then incubated for 2 days at $37^{\circ} \mathrm{C}$ in an atmosphere containing $5 \% \mathrm{CO}_{2}$. At the end of the incubation period, the cells were harvested and counted.

\section{Immunohistochemical localization of IGF-1R}

Punch biopsies $(4 \mathrm{~mm}$ ) were embedded in Tissue Tek optimal cutting temperature medium (Miles, Elkhart, Ind.), snap-frozen in liquid nitrogen and stored at $-70^{\circ} \mathrm{C}$ until use. Cryostat sections were cut at $5 \mu \mathrm{m}$ onto welled glass slides and were air dried. After fixation in cold acetone, the sections were incubated with the anti-IGF-1R monoclonal antibody. Staining was performed using the immunoperoxidase technique (ABC Kit, Vector, Burlington, Calif.). The chromogen used was 3-amino-9-ethyl-carbazole and the counterstain was $1 \%$ hematoxylin. Stained sections were examined by light microscopy.

\section{Affinity cross-linking of ${ }^{125}$ I-labeled IGF-1 to its receptor}

Cross-linking experiments were performed as previously described [17]. Briefly, keratinocytes grown to $60-80 \%$ confluency in KGM were rinsed in a pH 7.4 KRP buffer $(120 \mathrm{~m} M \mathrm{NaCl}, 5 \mathrm{mM} \mathrm{KCl}$, $\left.1 \mathrm{~m} M \mathrm{CaCl}_{2}, 1.2 \mathrm{~m} M \mathrm{MgSO}_{4}, 10 \mathrm{mM} \mathrm{Na} \mathrm{PO}_{4}\right)$ and binding was carried out at $4{ }^{\circ} \mathrm{C}$ for $6 \mathrm{~h}$ in KRP buffer containing $1 \%$ bovine serum albumin and $10 \mathrm{ng} / \mathrm{ml}{ }^{125} \mathrm{I}$-human IGF-1 (Amersham, Arlington Heights, Ill.). After washing in cold KRP buffer containing 1\% bovine serum albumin, cross-linking was performed in $1 \mathrm{~m} M$ disuccinimidyl suberate (Pierce, Rockford, Ill.), freshly prepared in dimethyl sulfoxide and KRP buffer for $15 \mathrm{~min}$ at $4{ }^{\circ} \mathrm{C}$. Cell lysates were then prepared and analyzed by gel electrophoresis and autoradiography.

\section{Results}

Effects of IGF-1, EGF, anti-IGF-1R antibody and anti-EGF-R antibody on keratinocyte growth in monolayer culture

Keratinocytes proliferated in the absence of either growth factor and both factors stimulated additional growth after 2 days. Antibody to the IGF-1R did not inhibit growth under basal conditions but suppressed growth induced by $10 \mathrm{ng} / \mathrm{ml} \mathrm{IGF-1} \mathrm{(50 \%} \mathrm{inhibition} \mathrm{at} 10 \mu \mathrm{g} / \mathrm{ml}$ antibody). In contrast, antibody to the EGF-R completely inhibited keratinocyte growth in basal medium in a concentration-dependent manner (> 90\% inhibition at $10 \mu \mathrm{g} / \mathrm{ml}$ antibody; Fig. 1).
Fig. 1 Keratinocyte proliferation in monolayer cultures under the influence of IGF-1, EGF, anti-IGF-1R antibody and anti-EGF-R antibody for 2 days (control keratinocytes maintained in $\mathrm{KBM}$ in the absence of either growth factor)

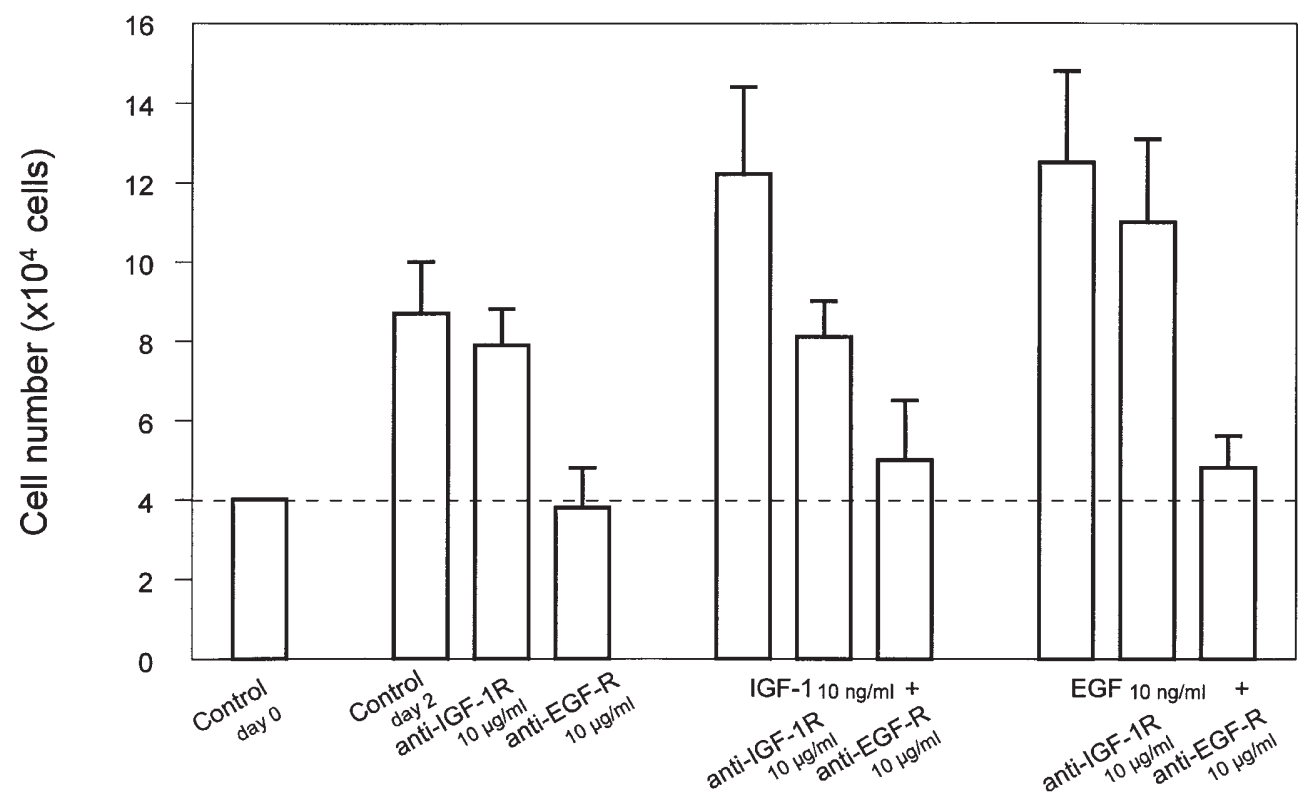


Fig. 2 A-F Histological features of human skin after incubation in organ culture for 9 days (A KBM alone,

B KBM with $1.4 \mathrm{mM} \mathrm{Ca}{ }^{2+}$

C $\mathrm{KBM}+2$ ng/ml IGF-1,

D $\mathrm{KBM}+10 \mathrm{ng} / \mathrm{ml} \mathrm{EGF}$, E KBM with $1.4 \mathrm{~m} M \mathrm{Ca}^{2+}$ and $10 \mu \mathrm{g} / \mathrm{ml}$ anti-IGF-1R antibody, F KBM with $1.4 \mathrm{mM}$ $\mathrm{Ca}^{2+}$ and $10 \mu \mathrm{g} / \mathrm{ml}$ anti-EGF-R antibody). $\mathrm{H} \& \mathrm{E}$, all $\times 66$

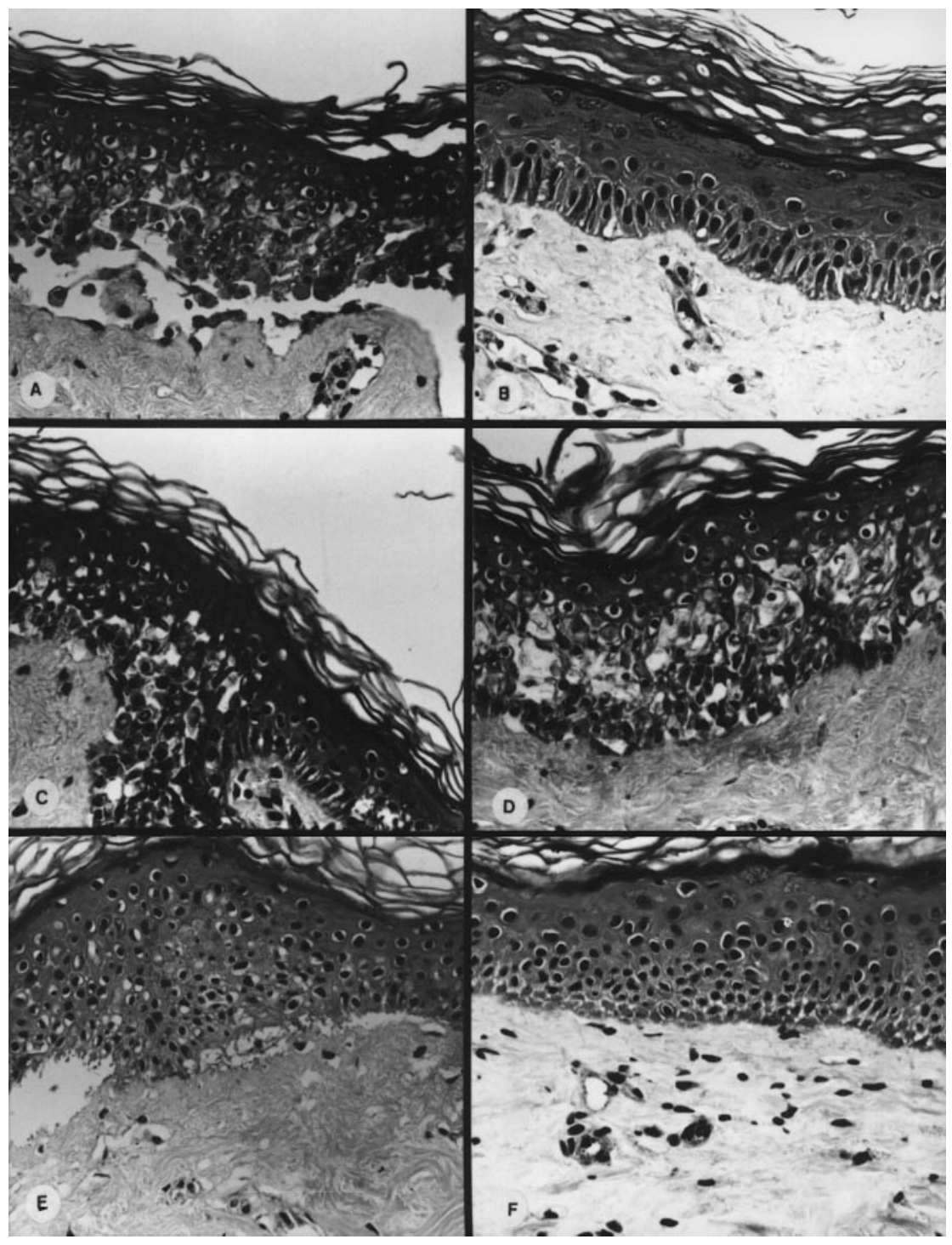

Effects of IGF-1, EGF, anti-IGF-1R antibody and anti-EGF-R antibody on skin in organ culture

Histological features of control organ-cultured skin maintained in KBM alone $\left(0.15 \mathrm{mM} \mathrm{C \textrm {Ca } ^ { 2 + }}\right)$ or in KBM supplemented with $\mathrm{Ca}^{2+}$ to a final concentration of $1.4 \mathrm{mM}$ are shown in Fig. 2A,B. Tissue structure was not preserved when the cultures were incubated in KBM alone. The epidermis separated from the dermis and there was complete necrosis in both epidermis and dermis. A timecourse study showed that necrosis could be seen within 2 days of incubation in low- $\mathrm{Ca}^{2+}$ medium and was virtually complete by 5-8 days. In contrast, tissue maintained in KBM supplemented with $1.4 \mathrm{~m} M \mathrm{Ca}^{2+}$ (final concentration) demonstrated a normal architecture after incubation for 9 days. In the epidermis, there was a basal layer of polarized epithelial cells with the normal stages of differentiation in the layers above. In the dermis, the connective tissue structures remained intact and most of the interstitial cell nuclei were lightly stained, plump and oblong.
The capillaries were lined with endothelial cells. Essentially, the features observed in the organ-cultured skin resembled features seen in fresh biopsy material. The major difference was a thinning of the epidermis as a function of time in culture. The number of polarized, non-pyknotic epithelial cells per unit length of basement membrane are shown in Table 1. There were few polarized, non-pyknotic epithelial cells in the tissue that had been incubated in low-Ca ${ }^{2+} \mathrm{KBM}$ alone $(5 \pm 3)$. In contrast, $58 \pm 5$ cells were counted per unit length of basement membrane in the tissue incubated in $\mathrm{Ca}^{2+}$-supplemented KBM. This compares with $72 \pm 13$ cells counted per unit length of basement membrane in fresh biopsy specimens $(n=7, \mathrm{~ns})$.

Experiments with IGF-1 or EGF added at various concentrations were performed in the low-Ca ${ }^{2+}$ medium. Figure $2 \mathrm{C}$,D shows the histological features of tissues incubated for 9 days in low-Ca ${ }^{2+}(0.15 \mathrm{mM}) \mathrm{KBM}$ supplemented with either IGF-1 $(2 \mathrm{ng} / \mathrm{ml})$ or EGF $(10 \mathrm{ng} / \mathrm{ml})$. Neither growth factor prevented degeneration of the tissue as re- 
Table 1 Quantification of polarized, non-pyknotic basal keratinocytes in organ-cultured skin maintained under various conditions. Cultures of 2-mm punch biopsies of human skin were maintained for 10 days in organ culture and treated as indicated. At the end of the incubation period, the tissues were prepared for histology and examined. Polarized, non-pyknotic basal keratinocyte numbers were assessed as described in the Materials and methods. The values shown are means and standard deviations based on duplicate sections from three to seven separate specimens per treatment group. Statistical significance was determined by ANOVA $(N S P>0.05$ vs the control value)

Treatment

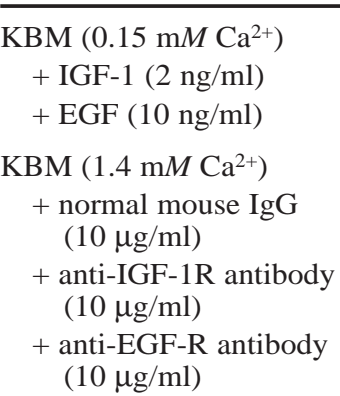

Fresh biopsy specimens treated tissue and in the quantitative data (Table 1). IGF-1 concentrations as high as $20 \mathrm{ng} / \mathrm{ml}$ and EGF concentrations as high as $50 \mathrm{ng} / \mathrm{ml}$ were used with identical results. The growth factor-rich KGM also completely failed to prevent tissue degeneration.

Experiments with antibodies to the IGF-1R and the EGF-R $(10 \mu \mathrm{g} / \mathrm{ml})$ were performed in the high-Ca ${ }^{2+}$ medium. Figure $2 \mathrm{E}, \mathrm{F}$ shows the effects of antibodies to the
IGF-1R and the EGF-R added to the cultures in KBM supplemented with $1.4 \mathrm{~m} M \mathrm{Ca}^{2+}$ (final concentration) and incubated for 9 days. Organ-cultured tissue incubated with antibody to the IGF-1R underwent complete degeneration within 9 days. There was essentially complete necrosis in both epidermal and dermal compartments and the epidermis partially separated from the dermis. In contrast, antibody to the EGF-R used under the same conditions did not produce such striking histological changes. There were no detectable abnormalities in the dermis. The epidermis also remained intact with a well-defined basal epithelial layer and the normal stages of differentiation above. Interestingly, although there were no gross abnormalities detected in the anti-EGF-R-treated organ cultures, there were focal areas of necrosis throughout the basal layer of epithelial cells. These histological changes seen in the presence of the antibodies to the two receptors are reflected

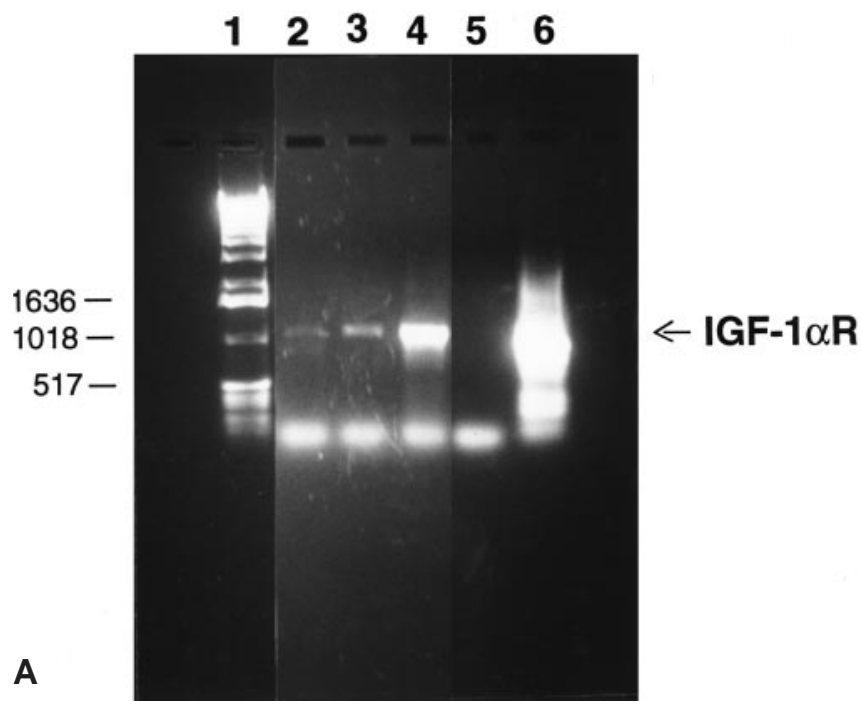

Fig. 3 Detection of IGF-1R mRNA by RT-PCR in organcultured skin under high- and low- $\mathrm{Ca}^{2+}$ conditions. A Lane 1 DNA marker ladder; lanes 2 and 3 pooled $(n=4)$ punch skin biopsies maintained in organ culture for 4 days under low$\mathrm{Ca}^{2+}$ and high-Ca ${ }^{2+}$ conditions, respectively; lane 4 intact skin; lane 5 negative control, no RNA; lane 6 IGF-1R plasmid. B Phosphorimager analysis of four individual samples after Southern blotting and hybridization against a ${ }^{32} \mathrm{P}-\mathrm{cDNA}$ probe for IGF-1R DNA (lanes $1,3,5$ and 7 individual samples maintained under low$\mathrm{Ca}^{2+}$; lanes 2, 4, 6 and 8 individual samples maintained under high-Ca ${ }^{2+}$; lane 9 keratinocyte RNA; lane 10 DNA template; lane 11 negative control)

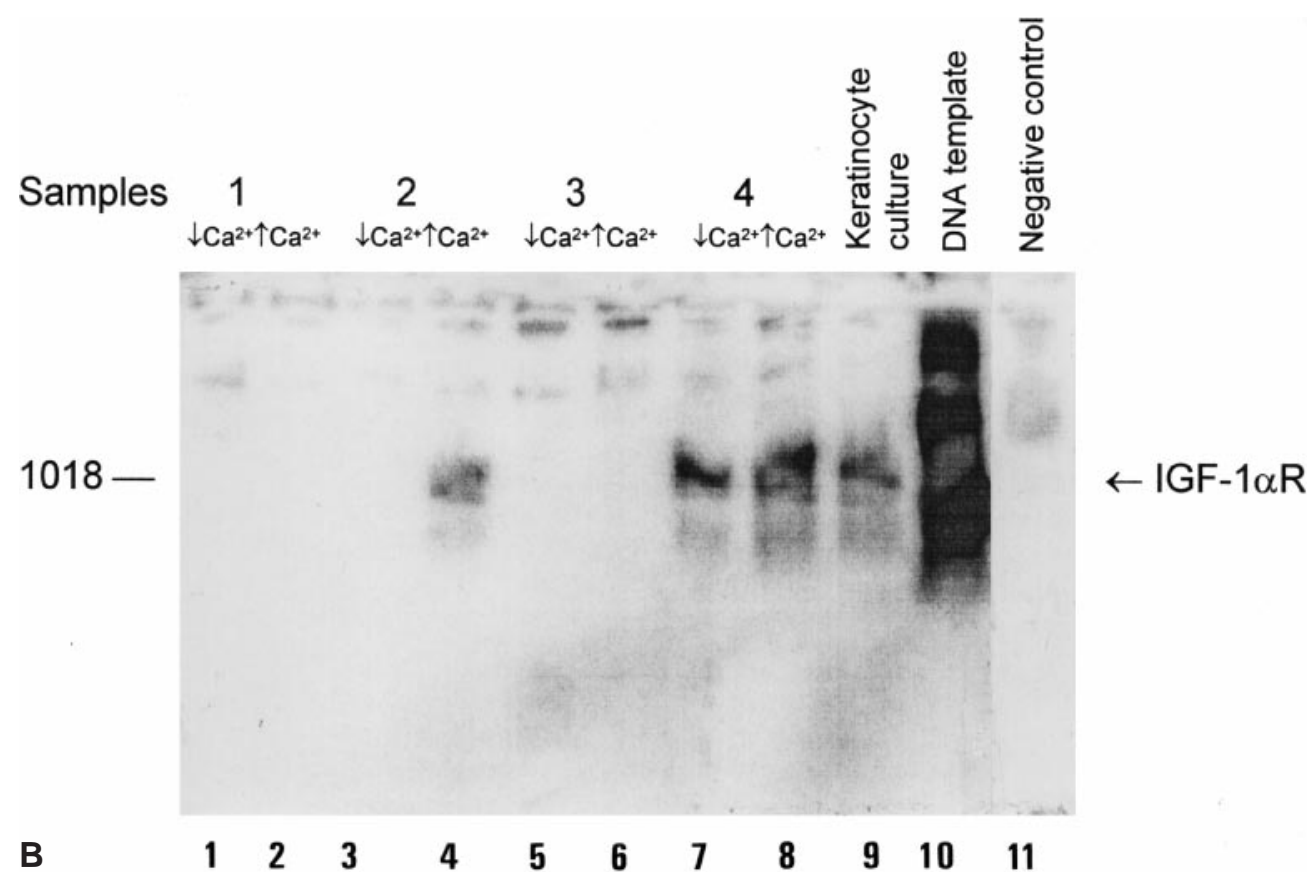


in the epithelial cell numbers shown in Table 1. Normal mouse IgG had no effect on epidermal or dermal structure.

IGF-1R mRNA and IGF-1 mRNA expression in human skin and skin cells

IGF-1R gene expression could be detected by RT-PCR in fresh biopsy skin (Fig. 3). mRNA expression was detected in human skin organ cultures after incubation for 4 days under conditions of low or high extracellular $\mathrm{Ca}^{2+}$, with a stronger signal intensity under high-Ca ${ }^{2+}$ conditions (pooled samples, $n=4$; Fig. 3A). The overall higher IGF-1R gene expression under elevated $\mathrm{Ca}^{2+}$ conditions was consistent with semiquantitative RT-PCR analysis of individual skin samples (run in duplicate). In the first skin sample, IGF$1 \mathrm{R}$ transcript was detected in tissue that had been maintained under high- $\mathrm{Ca}^{2+}$ conditions but not in tissue maintained under low- $\mathrm{Ca}^{2+}$ conditions. In the second sample, IGF-1R transcript was detected in tissue that had been maintained under either condition, but was expressed more strongly in the tissue that had been maintained under high$\mathrm{Ca}^{2+}$ conditions. In the last two samples, no IGF-1R-specific transcripts could be detected under any condition (Fig. 3B).

IGF-1 gene expression could also be detected by RTPCR in fresh biopsy skin and in the same samples of organcultured skin (Fig. 4). IGF-1-specific mRNA was found in specimens maintained for 4 days in KBM containing either low or high extracellular $\mathrm{Ca}^{2+}$. There was no detectable difference in mRNA expression between the two conditions. Cultured skin cells were additionally examined for IGF-1 gene expression (Fig. 5). IGF-1-specific mRNA was detected in endothelial cells, dermal fibroblasts, melano-

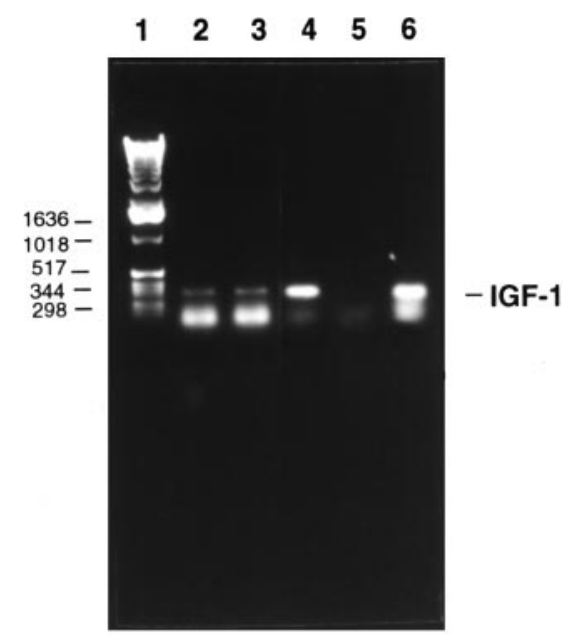

Fig. 4 Detection of IGF-1 mRNA by RT-PCR in organ-cultured skin under high- and low- $\mathrm{Ca}^{2+}$ conditions (lane 1 DNA marker ladder; lanes 2 and 3 pooled $(n=4)$ punch skin biopsies maintained in organ culture for 4 days under low- $\mathrm{Ca}^{2+}$ and high- $\mathrm{Ca}^{2+}$ conditions, respectively; lane 4 intact skin; lane 5 negative control, no RNA; lane 6 IGF-1 plasmid)

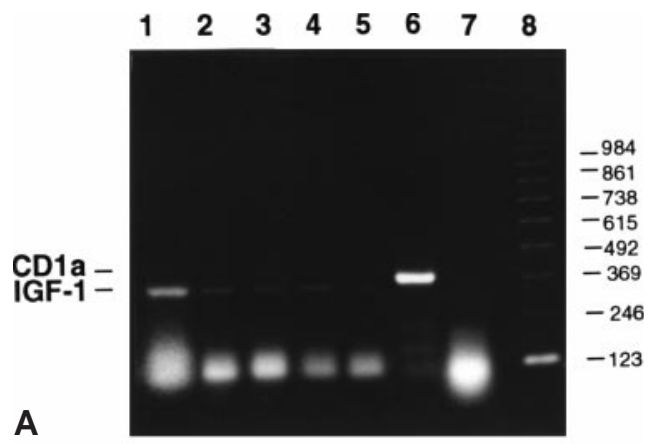

123456

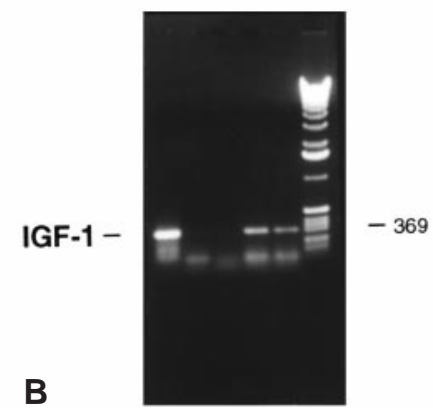

Fig. 5 A, B Detection of IGF-1 mRNA by RT-PCR in cultured skin cells. A Lane 1 endothelial cells; lane 2 dermal fibroblasts; lane 3 melanocytes; lane 4 skin-infiltrating T lymphocytes; lanes 5 and 6 Langerhans cells; lane 7 cell fraction depleted of Langerhans cells; lane 8 DNA marker ladder. B Lane 1 IGF-1 plasmid; lanes 2 and 3 two different keratinocyte preparations; lanes 4 and 5 intact skin samples; lane 6 DNA marker ladder)

cytes, skin-infiltrating T cells and affinity-purified Langerhans cells. The purity of the affinity-separated epidermal Langerhans cells used in RT-PCR experiments was determined through demonstration of CD1a mRNA in the affinity-purified Langerhans cell fraction but not in the cell suspension that had been depleted of Langerhans cells. In contrast to the results obtained with these various skin cell types, we were unable to detect IGF-1-specific mRNA in cultured keratinocytes using the same technique.

IGF-1R expression and cross-linking studies

Extensive IGF-1R staining was observed in the basal layer of normal skin by immunohistochemistry (Fig. 6). There was virtually no staining in suprabasal layers. Staining of single dermal cells was also observed.

To confirm IGF-1R expression in proliferating keratinocytes, keratinocytes maintained in an actively proliferating condition in vitro were used in cross-linking experiments (Fig. 7). ${ }^{125}$ I-IGF-1 was cross-linked predominantly to proteins with an apparent $\mathrm{M}_{\mathrm{r}}$ of 130,000 , which is consistent with the reported molecular weight of the $\alpha$-chain of IGF-1R [19]. Cross-linking was markedly inhibited by excess unlabeled IGF-1 (10 ng) indicating the specificity of binding. 


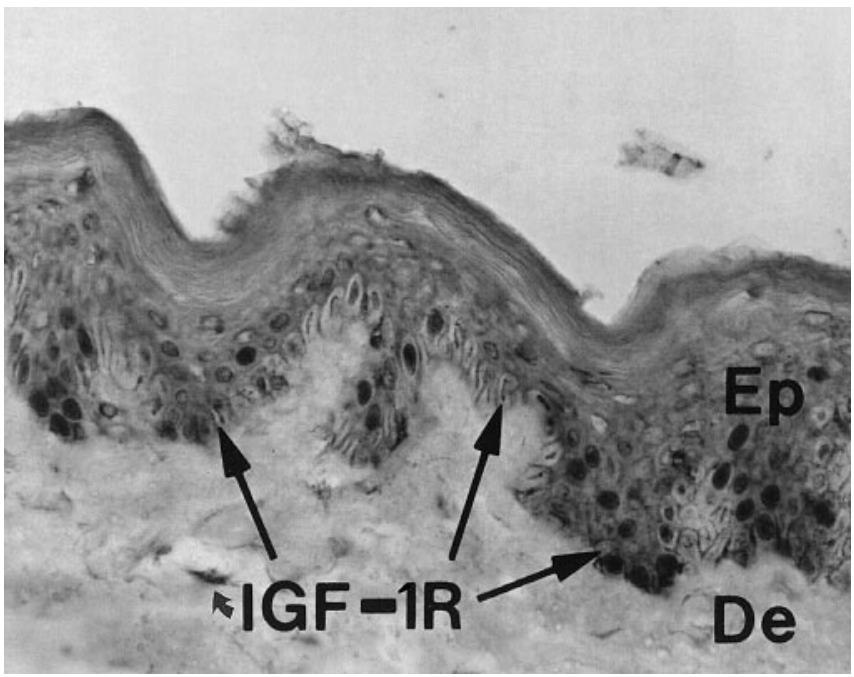

Fig. 6 Immunoperoxidase staining of frozen sections of human skin with an anti-IGF-1R antibody ( $\alpha 1 \mathrm{R}-3)$. Basal keratinocytes and single dermal cells are positively labeled (arrows). (Ep epidermis, De dermis; $\times 130$ )

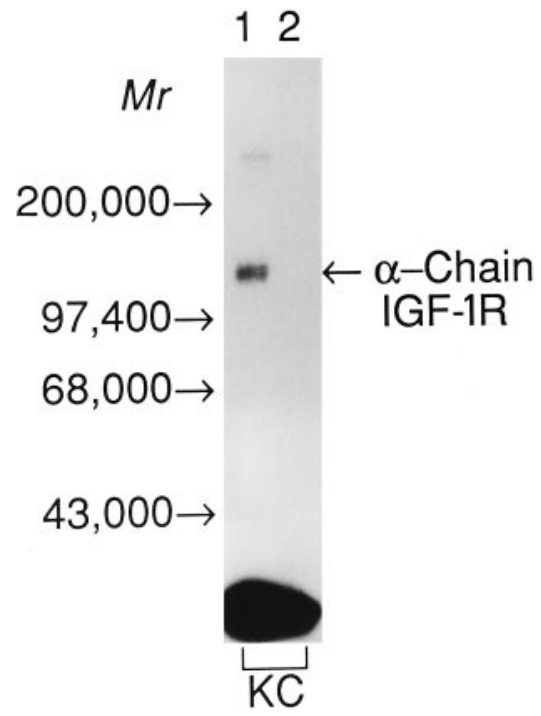

Fig. 7 Cross-linking of ${ }^{125}$ I-IGF-1 on the surface of proliferating cultured keratinocytes $(K C)$. Lane $1^{125} \mathrm{I}-\mathrm{IGF}-1$ affinity cross-linking to surface proteins of intact keratinocytes with an apparent $\mathrm{Mr}$ of 130,000; lane 2 complete inhibition of ${ }^{125}$ I-IGF-1 cross-linking by prior incubation of keratinocytes with a 100-fold excess unlabeled IGF-1

\section{Discussion}

Various lines of evidence suggest that the contribution of the dermis is critical to preservation of the epidermis as well as the dermis itself in organ-cultured skin. Incubation of the tissue under conditions that are optimal for keratinocyte growth in monolayer culture (i.e. in medium containing $0.15 \mathrm{mM} \mathrm{Ca}{ }^{2+}$ ) does not preserve tissue structure or function [24-26] while incubation of the tissue under conditions that maintain fibroblast viability in monolayer culture (i.e. in medium containing $1.4 \mathrm{mM} \mathrm{Ca}{ }^{2+}$ ) $[9,27]$ results in the maintenance of normal tissue architecture [4]. Further, a number of keratinocyte growth factors including IGF-1 [7, 28] and EGF [4, 5, 7, 29] do not preserve tissue maintained in low-Ca ${ }^{2+}$ medium while all-trans retinoic acid, which allows fibroblast survival and growth under low- $\mathrm{Ca}^{2+}$ conditions in monolayer culture [30], maintains the epidermis and dermis of organ-cultured skin in low-Ca ${ }^{2+}$ medium $[4,5,31]$. Histological changes are associated with a cessation of basal epithelial cell proliferation and with a virtual shutdown of overall protein synthesis $[4,5,31]$. Taken together, these reports suggest that maintenance of the epidermis as well as the dermis of skin in organ culture is dependent on dermal function. How this is brought about at the molecular level is not yet fully understood, and a number of different autocrine or paracrine growth factor loops may be involved.

Our findings suggest that IGF-1/IGF-1R constitutes one such loop. We were able to confirm that IGF-1R is present in the skin and that it is expressed on proliferating (basal) keratinocytes [8, 17, 29]. Likewise, IGF-1 itself appears to be present in the skin. Past studies have shown that IGF-1 is expressed by dermal fibroblasts $[8,17,32]$ and we demonstrated here using a RT-PCR technique that various cells in the skin (though not keratinocytes) express IGF-1 mRNA. mRNA for both receptor and ligand could be detected in whole skin cultured in vitro under conditions in which the structure and function of the skin were maintained. Further, IGF-1R mRNA was found to be expressed at lower levels under conditions that did not preserve tissue structure. Finally, and most importantly, it was observed that incubation with a monoclonal antibody to IGF-1R produced significant damage to the organ-cultured skin. Based on these observations, we suggest that the IGF-1/IGF-1R loop is critically important for maintaining structural integrity of human skin in organ culture [8].

How IGF-1 and its receptor help to maintain structural and functional integrity in skin is not fully understood and the mechanism is likely to be complex. The simplest hypothesis is that IGF-1 is a critical mitogen for keratinocytes [7] and that cells in the skin other than basal keratinocytes produce sufficient IGF-1 to facilitate basal epithelial cell proliferation. This would explain the severe degeneration seen in the epidermis following incubation of the organ-cultured skin in the presence of the anti-IGF$1 \mathrm{R}$ antibody. The data are also compatible with the apparent inability of keratinocytes to synthesize IGF-1 (present report and personal communication from Dr. James Krueger, Rockefeller University; [17]). The demonstration of IGF-1 production by epidermal keratinocytes of the stratum granulosum [8] is not contradictory to our results, since IGF-1 may also be an autocrine regulator of epidermal differentiation. This may explain the lack of IGF-1 expression in cultured keratinocytes growing under laboratory conditions designed to promote proliferation versus differentiation. Finally, there is compatibility with the data in monolayer culture presented here, showing that IGF-1 is capable of stimulating keratinocyte growth and that a monoclonal antibody to IGF-1R inhibits IGF-1-induced keratinocyte proliferation but has no effect on keratinocyte 
growth in the absence of IGF-1. Although this hypothesis is enticing, IGF-1 may act in some manner to preserve fibroblast viability and thus maintain the epithelium intact through an indirect mechanism, since IGF-1 is also a mitogen for fibroblasts [33].

While these data strongly indicate an important role for IGF-1/IGF-1R in the maintenance of organ-cultured skin in a viable condition, it is clear that this growth factor receptor loop is, by itself, insufficient. Addition of exogenous IGF-1 did not prevent the degeneration in either the epidermis or the dermis which occurred in low- $\mathrm{Ca}^{2+}$ culture medium. Perhaps a physiological $\mathrm{Ca}^{2+}$ level is required for optimal IGF-1R expression and function in keratinocytes and/or fibroblasts in organ culture. If the decreased IGF$1 \mathrm{R}$ mRNA expression seen in (low- $\left.\mathrm{Ca}^{2+}\right) \mathrm{KBM}$ alone is a direct consequence of low-Ca ${ }^{2+}$ incubation rather than a late consequence of tissue necrosis, then no amount of IGF-1 is likely to overcome this defect. Another possibility is that a number of growth factor loops must be concomitantly engaged to preserve dermal and epidermal integrity [2]. If this turns out to be the case, addition of no single growth factor will likely prevent degeneration.

Although most of the work described in this report dealt with IGF-1 and the IGF-1R, parallel experiments were conducted with an antibody to the EGF-R, which is also expressed in basal epidermal keratinocytes [34]. Unlike the anti-IGF-1R antibody, the antibody to the EGF-R did not induce widespread tissue degeneration. The overall appearance of the organ-cultured skin in the presence of the anti-EGF-R antibody was rather similar to that seen in the absence of the antibody or in the presence of a control mouse IgG. Interestingly, however, there were focal areas throughout the epidermis (possibly 10 to 15 cells across) where basal epithelial necrosis was evident. These areas of focal necrosis were present in an antibody concentration-dependent pattern and were not seen in the presence of normal mouse IgG. In addition, the antibody against EGF-R inhibited keratinocyte growth in vitro. These findings confirm recent findings of an inhibitory effect of antiEGF-R antibody on proliferation of basal keratinocytes without, however, induction of a toxic effect [10]. Based on this, we suggest that factors that function through the EGF-R also contribute to the maintenance of epidermal structure in organ culture, probably through inhibition of keratinocyte growth. EGF-R, in this context, may not play a critical role in the dermis, however, since the dermis appeared to be intact in the presence of the anti-EGF-R antibody.

In summary, the results presented here suggest the involvement of IGF-1/IGF-1R as well as factors that act through the EGF-R in preservation of skin in organ culture. While it is difficult to extrapolate the entire findings from in vitro studies to the situation in intact skin, our data make it reasonable to suggest the involvement of similar growth factor loops in vivo.

Acknowledgements This work has mainly been performed at the Departments of Dermatology and Pathology, The University of Michigan Medical School, Ann Arbor, Michigan, USA. The authors gratefully acknowledge the support of Drs. C. Griffiths, K.
Cooper, G. Fisher and H. Talwar in the preparation of the various cell populations and Dr. J. Mendelsohn for providing the antiEGF-R antibody. Dr. Zouboulis greatly appreciates the support of Dr. C.E. Orfanos for his professional development leave at the Department of Dermatology, The University of Michigan Medical School, Ann Arbor, Michigan, USA. Dr. Tavakkol was supported in part by the Babcock Fund for Dermatological Research and acknowledges the support of Dr. J. Voorhees throughout this work. Dr. Tavakkol also acknowledges excellent technical assistance of Ms. K. Kean and S. Foltin in carrying out some of the experiments described here. This study was supported in part by grant CA 60958 from the USPHS.

\section{References}

1. Piepkorn M, Pittelkow MR, Cook PW (1998) Autocrine regulation of keratinocytes: the emerging role of heparin-binding, epidermal growth factor-related growth factors. J Invest Dermatol 111: 715-721

2. Martin P (1997) Wound healing - aiming for perfect skin regeneration. Science 276: 75-81

3. Pincelli C, Yaar M (1997) Nerve growth factor: its significance in cutaneous biology. J Invest Dermatol Symp Proc 2: 31-36

4. Varani J, Fligiel SEG, Schuger L, Perone P, Inman DR, Griffiths CEM, Voorhees JJ (1993) Effects of all-trans retinoic acid and $\mathrm{Ca}^{2+}$ on human skin in organ culture. Am J Pathol 142: 189198

5. Varani J, Fligiel SEG, Perone P, Inman DR, Voorhees JJ (1993) Effects of sodium lauryl sulfate on human skin in organ culture: comparison with all-trans retinoic acid and epidermal growth factor. Dermatology 187: 19-25

6. Varani J, Perone P, Inman DR, Burmeister W, Schollenberger SB, Fligiel SE, Sitrin RG, Johnson KJ (1995) Human skin in organ culture. Elaboration of proteolytic enzymes in the presence and absence of exogenous growth factors. Am J Pathol 146: 210-217

7. Bhora FY, Dunkin BJ, Batzri S, Aly HM, Bass BL, Sidawy AN, Harmon JW (1995) Effect of growth factors on cell proliferation and epithelialization in human skin. J Surg Res 59: 236-244

8. Rudman SM, Philpott MP, Thomas GA, Kealey T (1997) The role of IGF-I in human skin and its appendages: morphogen as well as mitogen? J Invest Dermatol 109: 770-777

9. Boynton AL, Whitfield JF, Isaacs RJ, Tremblay R (1977) The control of human WI38 proliferation by extracellular calcium and its elimination by SV-40 virus-induced proliferative transformation. J Cell Physiol 92: 241-248

10. Stoll S, Garner W, Elder J (1997) Heparin-binding ligands mediate autocrine epidermal growth factor receptor activation in skin organ culture. J Clin Invest 100: 1271-1281

11. Liu SC, Karasek M (1978) Isolation and growth of adult human epidermal keratinocytes in cell culture. J Invest Dermatol 71: $157-162$

12. Varani J, Mitra RS, Gibbs D, Phan SH, Dixit VM, Wang T, Nickoloff BJ, Voorhees JJ (1990) All-trans retinoic acid stimulates growth and extracellular matrix production in growth-inhibited cultured human skin fibroblasts. J Invest Dermatol 94: 717-723

13. McCleric BK, Mitra RS, Riser BK, Nickoloff BJ, Dixit VM, Varani J (1989) Production and utilization of extracellular matrix components by human melanocytes. Exp Cell Res 180: 314-325

14. Varani J, Dame MK, Gibbs DF, Taylor CG, Weinberg JM, Shayevitz J, Ward PA (1992) Human umbilical vein endothelial cell killing by activated neutrophils: loss of sensitivity to injury is accompanied by decreased iron content during in vitro cultivation and is restored with exogenous iron. Lab Invest 66: 708-714 
15. Baadsgaard O, Tong P, Elder, TJ, Hansen ER, Ho V, Hammerberg C, Lange-Vejlsgaard G, Fox DA, Fisher GJ, Chan SL, Voorhees JJ, Cooper KD (1990) UM4D4+ (CDw60) T cells are compartmentalized into psoriatic skin and release lymphokines that induce a keratinocyte phenotype expressed in psoriatic skin. J Invest Dermatol 95: 275-282

16. Lisby S, Baadsgaard O, Cooper KD, Hansen ER, Mehregan D, Thomsen K, Allen E, Lange-Vejlsgaard G (1990) Phenotype, ultrastructure, and function of CD1+ DR+ epidermal cells that express CD36 (OKM5) in cutaneous T-cell Iymphoma. Scand J Immunol 32: 111-120

17. Tavakkol A, Elder JT, Griffiths CEM, Cooper KD, Talwar H, Fisher GJ, Keane KM, Foltin SK, Voorhees JJ (1992) Expression of growth hormone receptor, insulin-like growth factor I (IGF-I) and IGF-I receptor mRNA and proteins in human skin. J Invest Dermatol 99: 343-349

18. Kawasaki ES (1990) Amplification of RNA. In: Innis MA, Gelfand DH, Sninsky JJ (eds) PCR protocols: a guide to methods and applications. Academic Press, London, pp 21-27

19. Ullrich A, Gray A, Tam AW, Yang-Feng T, Tsubokawa M, Collins C, Henzel W, Le Bob T, Kathuria S, Chen E, Jacobs S, Francke U, Ramachandran J, Fujita-Yamaguchi Y (1986) Insulinlike growth factor I receptor primary structure: comparison with insulin receptor suggests structural determinants that define functional specificity. EMBO J 5: 2503-2512

20. Pagter-Holtuizen F de, Schaik MA van, Verduijn GM, Omman GJB van, Bouma BN, Jansen M, Sussenbach JS (1986) Organization of the human genes for insulin-like growth factors I and II. FEBS Lett 195: 179-184

21. Aruffo A, Seed B (1990) Expression of cDNA clones encoding the thymocyte antigens CDla, b, c demonstrates a hierarchy of exclusion in fibroblasts. J Immunol 143: 1723-1730

22. Sambrook J, Fritsch EF, Maniatis T (1989) Molecular cloning: a laboratory manual, 2nd edn. Cold Spring Harbor Laboratory Press, Cold Spring Harbor, New York

23. Zouboulis ChC, Voorhees JJ, Orfanos CE, Tavakkol A (1996) Topical all-trans-retinoic acid (RA) induces an early, coordinated increase of RA-inducible skin-specific gene/psoriasin and cellular RA binding protein II mRNA levels which precedes skin erythema. Arch Dermatol Res 288: 664-669

24. Hennings H, Michael D, Cheng C, Steinert P, Holbrook K, Yuspa SH (1980) Calcium regulation of growth and differentiation of mouse epidermal cells in culture. Cell 9: 245-254
25. Boyce ST, Ham RG (1983) Calcium regulated differentiation of normal human epidermal keratinocytes in chemically-defined clonal culture and serum-free serial culture. J Invest Dermatol 81: 33-40

26. Milstone LM (1987) Calcium modulates growth of human keratinocytes in confluent cultures. Epithelia 1: 129-140

27. Boynton AL, Whitfield JF, Isaacs RJ, Morton HJ (1974) Control of 3T3 cell proliferation by calcium. In Vitro 10: 12-17

28. Hodak E, Gottlieb AB, Anzilotti M, Krueger JG (1996) The insulin-like growth factor 1 receptor is expressed by epithelial cells with proliferative potential in human epidermis and skin appendages: correlation of increased expression with epidermal hyperplasia. J Invest Dermatol 106: 564-570

29.Zeigler ME, Dutcheshen NT, Gibbs DF, Varani J (1996) Growth factor-induced epidermal invasion of the dermis in human skin organ culture: expression and role of matrix metalloproteinases. Invasion Metastasis 16: 11-18

30. Varani J, Shayevitz J, Perry D, Mitra RS, Nickoloff BJ, Voorhees JJ (1990) Retinoic acid stimulation of human dermal fibroblast proliferation is dependent on suboptimal extracellular $\mathrm{Ca}^{2+}$ concentration. Am J Pathol 136: 1275-1281

31. Varani J, Larson BK, Perone P, Inman DR, Fligiel SEG, Voorhees JJ (1993) All-trans retinoic acid and extracellular $\mathrm{Ca}^{2+}$ differentially influence extracellular matrix production in human skin in organ culture. Am J Pathol 142: 1813-1817

32. Barreca A, De Luca M, Del Monte P, Bondanza S, Damonta G, Gariola G, Di Marco E, Giodano G, Cancedda R, Minuto F (1992) In vitro paracrine regulation of human keratinocyte growth by fibroblast-derived insulin-like growth factors. J Cell Physiol 151: $262-268$

33. Flier JS, Usher P, Moses AC (1986) Monoclonal antibody to the type I insulin-like growth factor (IGF-1) receptor blocks IGF-1 receptor-mediated DNA synthesis: clarification of the mitogenic mechanisms of IGF-1 and insulin in human skin fibroblasts. Proc Natl Acad Sci U S A 83: 664-668

34. Patel VG, Shum-Siu A, Heniford BW, Wieman TJ, Hendler FJ (1994) Detection of epidermal growth factor receptor mRNA in tissue sections from biopsy specimens using in situ polymerase chain reaction. Am J Pathol 144: 7-14 